\title{
Peptida Antimikrobial Cathelicidin dan Liposom sebagai Pembawa
}

\author{
Mayang Kusuma Dewi ${ }^{\star 1}$, Anis Yohana $C^{2}$, Sriwidodo 3
}

\begin{abstract}
${ }^{1}$ Program Studi Magister Farmasi, Fakultas Farmasi, Universitas Padjadjaran, Jl. Raya Bandung
Sumedang km 21 Jatinangor 45363, Jawa Barat, Indonesia

2Departemen Teknologi Farmasi dan Farmasi, Fakultas Farmasi, Universitas Padjadjaran, JI. Raya

Bandung Sumedang km 21 Jatinangor 45363, Jawa Barat, Indonesia

*E-mail: mayang14001@mail.unpad.ac.id
\end{abstract}

(Submit 25/4/2021, Revisi 19/5/2021, Diterima 23/5/2021, Terbit 25/5/2021)

\begin{abstract}
Abstrak
Peptida antimikrobial (PAM) dalam beberapa tahun terakhir telah menarik perhatian di kalangan ilmuwan, profesional kesehatan, dan perusahaan farmasi karena potensi terapeutiknya yang sangat luas. Cathelicidin merupakan salah satu kelompok dari PAM dengan berat molekul rendah yang mempunyai berbagai aktivitas biologis pada rentang terapi tertentu yang berfungsi sebagai antimikrobial, antivirus, dan antijamur, serta dapat memodulasi sistem imum terhadap infeksi bakteri (gram positif dan gram negatif). Walaupun menarik untuk aplikasi klinis, cathelicidin memiliki keterbatasan dalam hal stabilitas dan aktivitasnya secara in-vivo, serta interaksi non-spesifik dengan membran biologis inang yang mengarah pada efek sitotoksik yang merugikan. Enkapsulasi cathelicidin dapat mengakibatkan penurunan sitotoksisitas, meningkatkan stabilitas dan aktivitas biologisnya. Keterbatasan cathelicidin dapat diatasi dengan mengenkapsulasi cathelicidin dalam pembawa lipid seperti liposom. Review ini bertujuan untuk memberikan gambaran singkat mengenai struktur, sifat, fungsi, uji klinis, dan keterbatasan dari cathelicidin yang mana keterbatasan cathelicidin ini dapat di atasi dengan pembawa vesikular salah satunya adalah liposom. Liposom merupakan pembawa vesikular generasi pertama yang bersifat non-toksik, biodegradable, biokompatibel, dan stabil dalam larutan koloid sistem penghantaran obat. Sistem liposom dapat melindungi peptida yang dienkapsulasi dari degradasi protease. Selain itu, pembawa liposom disajikan sebagai alternatif yang menjanjikan untuk mengoptimalkan pemberian cathelicidin dalam hal dosis, pola pengiriman, dan keamanan.
\end{abstract}

Kata kunci: Cathelicidin, sifat cathelicidin, sturktur cathelicidin, mekanisme cathelicidin, keterbatasan cathelicidin, liposom 


\section{Pendahuluan}

Peptida antimikrobial (PAM) adalah kelompok molekul yang diproduksi oleh sel dan jaringan dalam tubuh organisme hidup, yang memiliki peran penting sebagai sistem pertahanan tubuh. Prokariot dan manusia diketahui memproduksi PAM dalam tubuh mereka (1). Sistem imun bawaan memainkan peran penting dalam pertahanan melawan mikroba serta dalam inisiasi respon inflamasi pada organisme eukariotik. Ratusan PAM disintesis oleh sel epitel dan limfosit (2).

Manusia menghasilkan dua kelas PAM yaitu defensin dan cathelicidin. Dalam review ini hanya akan berfokus pada cathelicidin, mulai dari struktur hingga keterbatasan dari cathelicidin serta cara untuk mengatasi keterbatasan cathelicidin tersebut. Cathelicidin dinamai berdasarkan kemampuannya untuk menghambat protease cathepsin-L, yang merupakan peptida kelompok besar dan beragam yang mengandung domain terminal$\mathrm{N}$ yang dikonservasi yang disebut domain cathelin. Aktivitas antimikrobial cathelicidin dihasilkan melalui penghilangan proteolitik domain cathelin sebagai bagian dari proses sekresi (3). Banyak publikasi yang menunjukan sifat antimikrobial dari Cathelicidin terhadap berbagai patogen $(4,5,6)$.

Dalam beberapa tahun terakhir, PAM telah mendapatkan perhatian yang lebih di kalangan ilmuwan, profesional kesehatan dan perusahaan farmasi karena potensi terapeutiknya yang sangat luas. Meskipun menarik untuk aplikasi klinis, agen ini memiliki keterbatasan dalam hal stabilitas dan aktivitas in-vivo, karena penguraian enzimatik oleh peptidase dan interaksi dengan spesies anionik cairan tubuh dan membutuhkan matriks pelindung untuk memungkinkan pengobatan yang efisien $(7,8,9)$.

Beberapa penelitian telah dilakukan untuk mengatasi ketebatasan cathelicidin (10). Kemajuan dalam nanoteknologi telah memungkinkan struktur nanoenkapsulasi sebagai strategi untuk meminimalkan karakteristik yang tidak diinginkan dari PAM (11). Telah dilaporkan bahwa peptida dalam struktur nanopartikel menunjukkan sitotoksisitas yang lebih rendah, mengurangi degradasi dan meningkatkan efisiensi pada target yang diinginkan (12,13). Dalam penelitian yang dilakukan oleh Garcia-Orue et al (2016), cathelicidin dienkapsulasi dalam pembawa Nanostructured Lipid Carrier (NLC), diproduksi dengan metode emulsi-leleh, untuk meningkatkan efektivitasnya (14).

Ron-Doitch (2016) melakukan penelitian dimana cathelicidin dienkapsulasi dalam pembawa liposom untuk tujuan terapi Herpes Simplex 1 Virus (HSV-1). Pada penelitian yang dilakukan Ron-Doitch, formulasi liposom-cathelicidin dilakukan dengan modifikasi permukaan yang dikenal dengan PEGylation yang bertujuan untuk mengurangi efek samping sistemik, dan meningkatkan kemanjuran terapeutik (15). Enkapsulasi cathelicidin dalam pembawa liposom disajikan sebagai alternatif yang menjanjikan untuk mengoptimalkan pemberian cathelicidin dalam hal dosis, pola pengiriman, dan keamanan (16). 
Sistem liposom dapat melindungi peptida yang dienkapsulasi dari degradasi protease sehingga dapat diberikan melalui rute topikal yang memiliki risiko penguraian proteolitik oleh sejumlah proteinase bakteri (16). Review ini bertujuan untuk memberikan gambaran singkat mengenai struktur, sifat, fungsi, uji klinis, dan keterbatasan dari cathelicidin yang mana keterbatasan cathelicidin ini dapat di atasi dengan pembawa vesikular salah satunya adalah liposom.

\section{Cathelicidin}

Manusia hanya mengekspresikan satu protein cathelicidin, yang diidentifikasi pada tahun 1995 dan dinamai hCAP18 (human cationic antimicrobial peptide) (17). Pada manusia, cathelicidin dihasilkan dari propotein hCAP18 yang merupakan bentuk tidak aktif dari cathelicidin. Gen cathelicidin mengkodekan prekursor protein 18 kDa hCap-18 yang melepaskan ujung atau terminal C aktif 37 asam amino (LLGDFFRKSKEKIGKEFKRIVQRIKDFLRNLVPRTES) pada saat pemrosesan. Nama LL-37 berasal dari dua residu pertama dari ujung terminal $C$ yaitu leusin dan terminal $C$ tersebut terdiri dari 37 residu asam amino (dapat dilihat pada gambar 1) $(10,11)$.

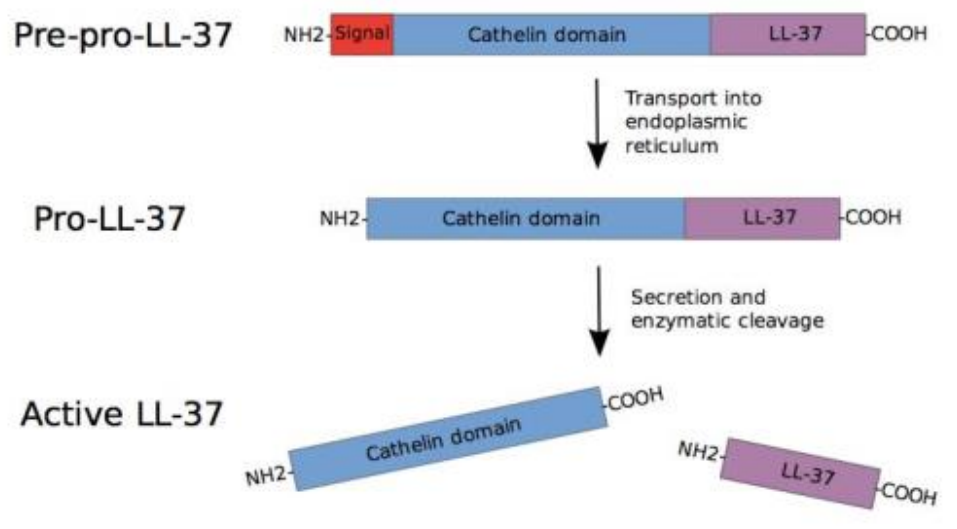

Gambar 1 Proses pembentukan Cathelicidin (LL-37) (20).

hCAP 18 disimpan dalam neutrofil pada konsentrasi molar setinggi laktoferin (40 $\mu \mathrm{mol}$ atau $630 \mu \mathrm{g} / 10^{9} \mathrm{sel}$ ), yang merupakan bagian substansial protein dalam neutrofil (21). Tiga protease yang dikenal dalam neutrofil (elastase, cathepsin G, dan proteinase 3 ) telah terbukti dapat membelah hCAP-18 secara in-vitro. Namun, hanya proteinase 3 yang telah ditemukan mampu membelah dua-domain protein menjadi mature peptida dan bagian cathelin dari neutrofil (22). Proteinase 3 disimpan dalam neutrofil peroksidase, terpisah dengan baik dari hCAP18. Kedua protein ini terkait baik dalam fagolysozymes yang terbentuk selama proses fagositik atau secara ekstraseluler setelah degranulasi. Meskipun hCAP-18 dan proteinase 3 telah terdeteksi dalam fagolysozymes, analisis terperinci menunjukkan bahwa pemrosesan hCAP-18 hanya terjadi di luar neutrofil (23). 


\section{Aktivitas Biologi Cathelicidiin}

Cathelicidins bertindak sebagai pertahanan utama terhadap bakteri dan patogen lain dalam kasus inflamasi. Cathelicidin mampu membunuh bakteri dan jamur (24), menghambat dan menghancurkan biofilm bakteri (25) memiliki aktivitas sebagai antivirus $(27,28)$ dan aktivitas antiparasit (terhadap Entamoeba hystolitica) (28). Cathelicidin juga dapat memodulasi dan/ atau merangsang sel-sel sistem kekebalan tubuh, memengaruhi sistem imun innate maupun adaptive (29), memainkan peran dalam angiogenesis $(31,32)$, penyembuhan luka (32), dan mengatur apoptosis (33). Beberapa perkiraan konsentrasi dari berbagai aktivitas Cathelicidin dapat dilihat pada gambar 2.

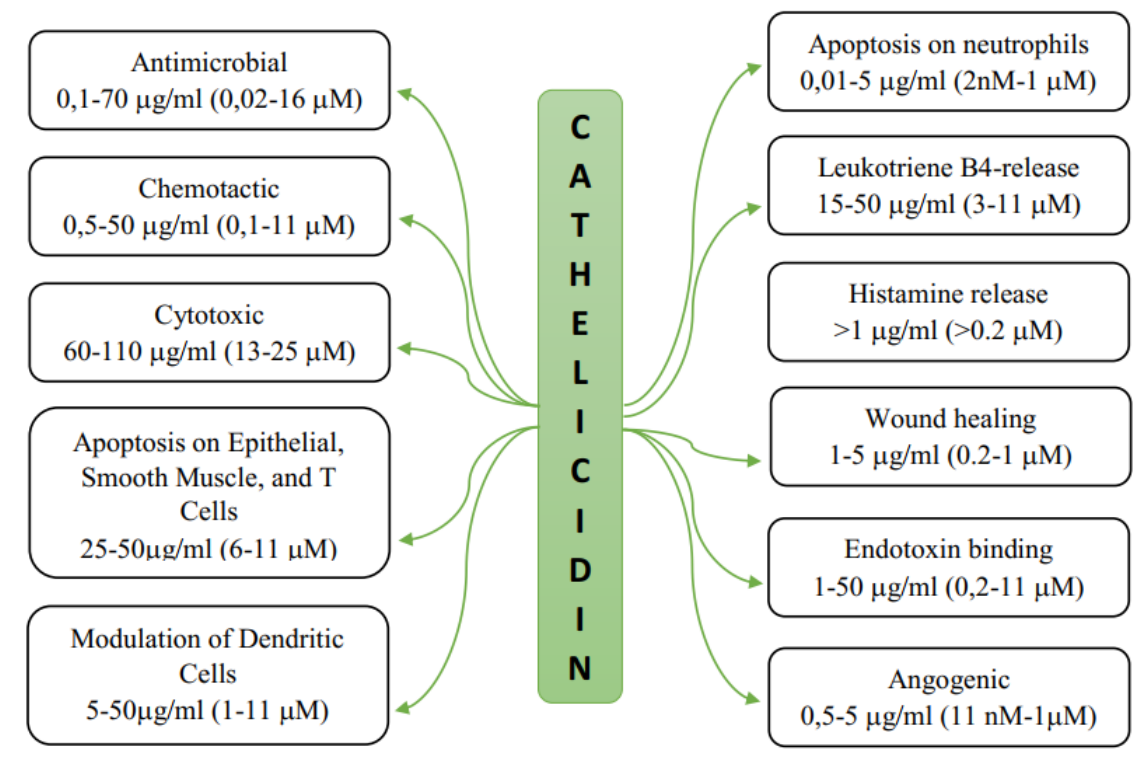

Gambar 2 Perkiraan konsentrasi dari berbagai aktivitas Cathelicidin (34).

\section{Sifat Fisikokimia Cathelicidin}

Cathelicidin merupakan peptida antimikrobial yang terdiri dari 37 asam amino dengan dua residu pertama dari ujung terminal $C$ adalah leusin (18). Sifat fisiko kimia dari cathelicidin LL37 dapat dilihat pada tabel 1. 
Tabel 1 Sifat Fisiko kimia Cathelicidin (35)

\section{Sifat Fisikokimia}

Rumus molekul

Berat molekul

Sequence

IUPAC

Terkondensasi

Donor Ikatan

Hidrogen

Akseptor Ikatan

Hidrogen

Rotatable Bond

\section{Cathelicidin}

$\mathrm{C}_{207} \mathrm{H}_{341} \mathrm{~F}_{3} \mathrm{~N}_{60} \mathrm{O}_{55}$ $4607 \mathrm{~g} / \mathrm{mol}$

\section{LLGDFFRKSKEKIGKEFKRIVQRIKDFLRNLVPRTE} $S$

H-Leu-Leu-Gly-Asp-Phe-Phe-Arg-Lys-Ser-Lys-GluLys-Ile-Gly-Lys-Glu-Phe-Lys-Arg-Ile-Val-Gln-Arg-IleLys-Asp-Phe-Leu-Arg-Asn-Leu-Val-Pro-Arg-Thr-GluSer-OH.TFA

69

70

166

\section{Struktur Cathelicidin}

54\% residu cathelicidin bersifat hidrofilik dengan 11 basa dan 5 asam, memberikan muatan positif sebesar \pm 6 pada $\mathrm{pH}$ fisiologis. Dalam larutan aqueous, cathelicidin menunjukan spektrum circular dichroism yang konsisten dengan struktur yang tidak teratur (tabel 2 A). Namun, dalam membran di mana lingkungannya lipofilik, banyak asam amino dapat membentuk ikatan hidrogen intramolekul yang mengunci struktur sekunder menjadi a-helix (25).

Ciri khas dari a-heliks LL-37 adalah sifat ampifatiknya, diilustrasikan oleh roda heliks (Tabel 2 B). Struktur sekunder, dilihat ke dalam koil, menunjukan sisi lipofilik dan sisi polar yang bermuatan positif pada pH fisiologis $(7,4)$ (Tabel $2 \mathrm{C})$. Untuk memperkirakan konformasi cathelicidin dalam membran, struktur NMR tiga dimensi telah dijelaskan dalam dodecylphosphocholine micelles (Tabel 2 D) (36). Dengan cara yang sama, sebuah studi spektroskopi NMR tiga-resonansi tiga-dimensi LL-37 dalam misel SDS dilakukan (37). Dalam kondisi ini, ampifatik struktur kationik-heliks ditemukan yang mencakup residu 2 hingga 31 dengan residu C-terminal 32 hingga 37 tidak terstruktur dan melengkung dengan rantai samping hidrofobik. Keempat rantai samping fenilalanin aromatik membentuk permukaan hidrofobik cathelicidin yang dibatasi oleh residu bermuatan positif, memungkinkan interaksi dengan molekul atau struktur bermuatan negatif, seperti dinding sel bakteri, LPS, dan bahan genetik (37) 
Terlihat bahwa N-terminal heliks dari cathelicidin terlibat dalam resistensi proteolitik, oligomerisasi peptida, aktivitas hemolitik dan kemotaksis. Selanjutnya heliks C terminal bertanggung jawab atas efek antimikroba, antikanker dan antivirus (38).

Tabel 2 Struktur sekunder cathelicidin

LL-37 dalam media aquoeus
menunjukkan konformasi yang tidak
terstruktur (18).




\section{Uji Klinik}

Cathelicidin memiliki aktivitas spektrum yang sangat luas, salah satunya adalah sebagai agen untuk penyembuhan luka. Telah dilakukan uji klinik fase II dimana cathelicidin berfungsi sebagai obat untuk ulserasi tungkai bawah (venous leg ulcer) yang bertujuan untuk meningkatkan penyembuhan luka pada kelompok pasien dengan luka yang tidak sembuh yang diformulasikan dalam bentuk sediaan gel (40). Pengembangan obat topikal untuk penyembuhan luka saat ini sangat dipengaruhi oleh kebutuhan untuk mengurangi penyebaran resistensi antibiotik (41).

Penyembuhan luka adalah jalur dinamis yang secara optimal mengarah pada pemulihan integritas dan fungsi jaringan. "Luka kronis" adalah luka yang proses penyembuhannya berkepanjangan yang mengakibatkan kurangnya pemulihan integritas. Hard-to-heal (HTH) atau ulkus kronis merupakan salah satu contoh dari luka kronis. Ulkus yang sulit untuk disembuhkan pada kaki, seringkali menyakitkan, menstigmatisasi, dan berdampak negatif pada kemampuan fungsional Venous leg ulcers (VLUs) merupakan ulserasi kulit dan subkutan kronis yang terjadi pada kaki bagian bawah, antara lutut dan malleolus (40).

LL-37 berdampak pada beberapa mekanisme biologis yang relevan dalam penyembuhan luka. Peptida menarik sel-sel inflamasi, termasuk monosit dan granulosit. Diketahui bahwa LL-37 memodulasi fase inflamasi penyembuhan luka melalui pelepasan protein dan peptida yang mengatur urutan inflamasi (sitokin) (42). Keratinosit (sel epitel kulit) diaktifkan oleh LL-37, yang pada gilirannya menghasilkan aktivasi faktor pertumbuhan pada lapisan kulit luar dengan migrasi sel yang konsekuen. Ini diasumsikan menghasilkan re-epitelisasi dan penutupan luka (43). Selain itu, produksi faktor pertumbuhan vaskular seperti VEGF dan aktivasi sel endotel dalam pembuluh darah juga penting untuk pembentukan pembuluh darah baru yang diamati setelah pengobatan dengan LL-37.

Penelitian in vivo dengan cathelicidin sintetik telah menunjukkan bahwa injeksi subkutan merangsang angiogenesis dan pemberian topikal berulang pada luka akut menarik selsel inflamasi ke jaringan di sekitarnya (44). Peningkatan yang nyata dan signifikan dalam penyembuhan luka diamati sebagai respon terhadap pemberian dua dosis rendah LL -37 (0,5 dan 1, $6 \mathrm{mg} / \mathrm{mL})$. Hasil dari penelitian ini menunjukkan bahwa dosis 0,5 (yang setara dengan $13 \mathrm{mg} \mathrm{LL}-37$ per $\mathrm{cm} 2$ area luka), dan $1,6 \mathrm{mg} / \mathrm{mL}$ (yang setara dengan $40 \mathrm{mg}$ LL - 37 per $\mathrm{cm} 2$ area luka) setiap hari ketiga menghasilkan stimulasi penyembuhan luka yang signifikan (40).

\section{Keterbatasan Cathelicidin}

Walaupun menarik untuk aplikasi klinis, cathelicidin memiliki keterbatasan dalam hal stabilitas dan aktivitasnya secara in vivo, serta interaksi non-spesifik dengan membran biologis inang, yang mengarah pada efek sitotoksik yang merugikan. Enkapsulasi Cathelicidin dapat mengakibatkan penurunan sitotoksisitas, meningkatkan stabilitas dan aktivitas biologisnya (45). Selain itu, enkapsulasi dapat melindungi obat (peptide) dari degradasi (46) (47). 
Terdapat beberapa penelitian yang mengenkasulasi cathelicidin dengan beberapa pembawa lipid seperti liposom (45), Solid Lipid Nanopartikel (48), Nanostructured Lipid Carrier (14), dan Cubosome (49). Dari penelitian tersebut, terbukti bahwa dengan mengenkapsulasi cathelicidin dalam pembawa lipid, dapat mengatasi keterbatasan cathelicidin.

\section{Liposom}

Liposom merupakan pembawa vesicular generasi pertama. Liposom pertama kali diperkenalkan oleh Dr. Alec D. Bangham FRS pada tahun 1961 dari Institute Babraham di Cambridge. Liposom tersusun atas fosfolipid yang dalam medium aquoeus membentuk struktur bilayer (50). Kemudian, struktur bilayer tersebut disebut sebagai liposom oleh Sessa. Awalnya, liposom digunakan untuk mempelajari sifat fisik membran biologis seperti orientasi lipid dalam bilayer, sifat fisiokimia lipid dan transport ion melaui membrane biologis (51). Namun pada saat ini, liposom banyak digunakan sebagai pembawa pada sistem penghantaran obat karena memenuhi semua persyaratan pembawa obat yang baik.

Liposom bersifat non-toksik, biodegradable, biokompatibel, dan stabil dalam larutan koloid sistem penghantaran obat. Liposom berbentuk spheris (bulat) dengan membran yang yang bersifat ampifilik, terdiri dari bilayer (lipid alami maupun sintetik) yang keduanya biokompatibel dan biodegradable. Sistem penghantaran obat liposom bertujuan untuk mengubah sifat farmakokinetik dan/ atau farmakodinamik dari suatu obat. Liposom ini dapat mengatasi berbagai kekurangan seperti efikasi rendah, bioavailabilitas rendah dan toksisitas tinggi $(54,55)$.

Liposom dapat mengenkapsulasi obat baik yang bersifat hidrofilik maupun yang bersifat lipofilik. Hal ini dikarenakan struktur liposom yang terdiri dari kepala dan ekor yang bersifat ampifili., Ekor liposom bersifar polar dan kepala liposom bersifat nonpolar $(56,55)$.

Fosfolipid pembentuk liposom dapat berasal dari sintetik maupun alami. Fosfolipid tak jenuh yang berasal dari alam seperti egg atau soybean phosphatidylcholine memberikan lapisan bilayer yang lebih permeabel dan kurang stabil, sedangkan fosfolipid jenuh yang berasal dari sintetis seperti dipalmitoylphos phatidylcholine membentuk bilayer yang rigid (53).

Temperatur fase transisi (Tc) fosfolipid merupakan kriteria penting untuk memilih fosfolipid untuk preparasi liposom (55). Suhu fase transisi didefinisikan sebagai suhu di mana keadaan fisik lipid berubah dari fase gel menjadi fase kristal cair yang tidak teratur. Konversi fase tergantung pada panjang rantai hidrokarbon, derajat kejenuhan, dan muatannya $(57,58)$. 


\section{Komposisi Liposom}

Liposom tersusun atas fosfolipid, kolesterol, dan buffer. Fosfolipid berasal dari asam fosfatidat yang merupakan backbone dari gliserol. Gliserol yang mengandung fosfolipid adalah komponen yang paling umum digunakan dalam formulasi liposom dan mewakili lebih dari $50 \%$ berat lipid dalam membran biologis (57). Fosfolipid memiliki kemampuan untuk merakit diri secara spontan dalam media aquoeus dan membentuk satu atau beberapa bilayer. Fosfolipid memiliki gugus kepala hidrofilik dan ekor hidrofobik yang membuatnya tidak larut dalam air kecuali jika mereka merakit diri menjadi bilayer (58).

Kolesterol sering ditambahkan untuk meningkatkan stabilitas bilayer dengan adanya cairan biologis. Kolesterol, sebagai molekul ampifilik, dengan ekor karbohidrat fleksibel dan gugus hidroksil yang mampu membentuk ikatan hidrogen dengan fosfolipid. kolesterol berfungsi untuk mengatur permeabilitas, elastisitas dan kekakuan membran. Selain itu, secara signifikan mengurangi deformabilitas membran dan mobilitas protein. Kolesterol, sebagai sterol yang paling umum digunakan dalam formulasi liposom, mampu mencegah agregasi dan meningkatkan stabilitas membran liposom. Buffer digunakan untuk menghidrasi liposom. Buffer yang biasa digunakan untuk pembuatan liposom adalah buffer fosfat (59).

\section{Pembentukan liposom}

Liposom adalah vesikel yang tersusun dari molekul amfifilik dalam konformasi bilayer. Fosfolipid banyak digunakan dalam pembuatan liposom, memiliki bentuk silinder, dengan kepala polar (hidrofilik) dan dua rantai asil nonpolar (hidrofobik). Dalam media air (aqueous), molekul fosfolipid merakit dirinya sendiri (self-assemble) menjadi struktur bilayer di mana gugus hidrofobik berinteraksi satu sama lain dan diarahkan ke dalam, dan bagian hidrofilik diorientasikan di luar, berinteraksi dengan air (60). Struktur tersebut dapat dilihat pada (Gambar 3).
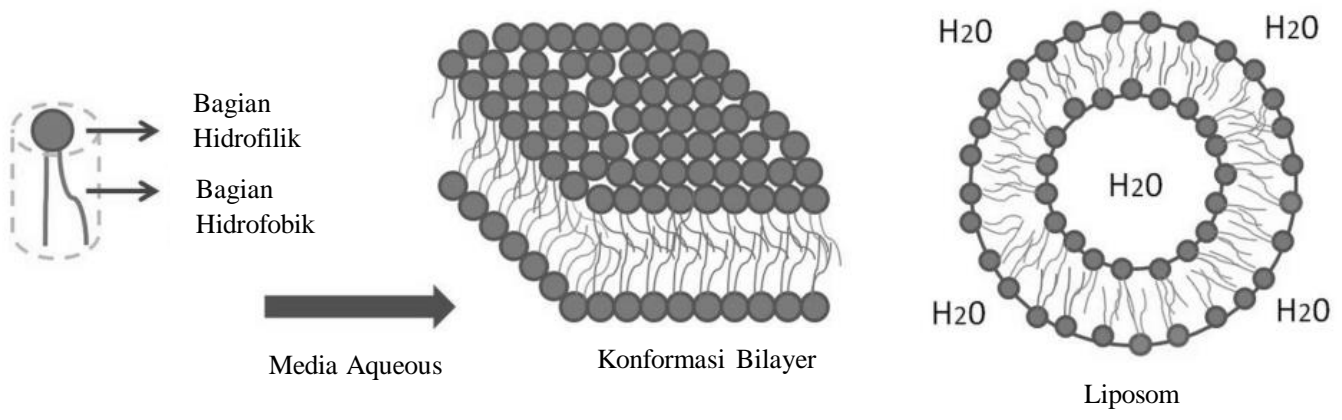

Gambar 3 Liposom - lipid amfifilik dengan struktur molekul silindris. Dalam media aqueous, diatur dalam struktur bilayer vesikel yang tertutup 
Dalam bilayer, gugus polar fosfolipid berbaris membentuk permukaan yang menarik air sementara rantai lipofiliknya saling berhadapan untuk menghasilkan zona bebas air. Pada pengadukan atau pemanasan mekanis, fosfolipid bilayer terus menerus menutupi medium berair dan membentuk sistem vesikuler. Dalam sistem ini, gugus hidrofilik fosfolipid berorientasi pada fase air dalam dan luar, sedangkan ekor hidrofobiknya berpusat di dalam lapisan ganda $(63,64)$. llustrasi (Gambar 4) ini menggarisbawahi kemampuan liposom untuk dengan mudah mengenkapsulasi material hidrofilik dan hidrofobik di dalam inner aqueous core dan lipid bilayers, masing-masing.
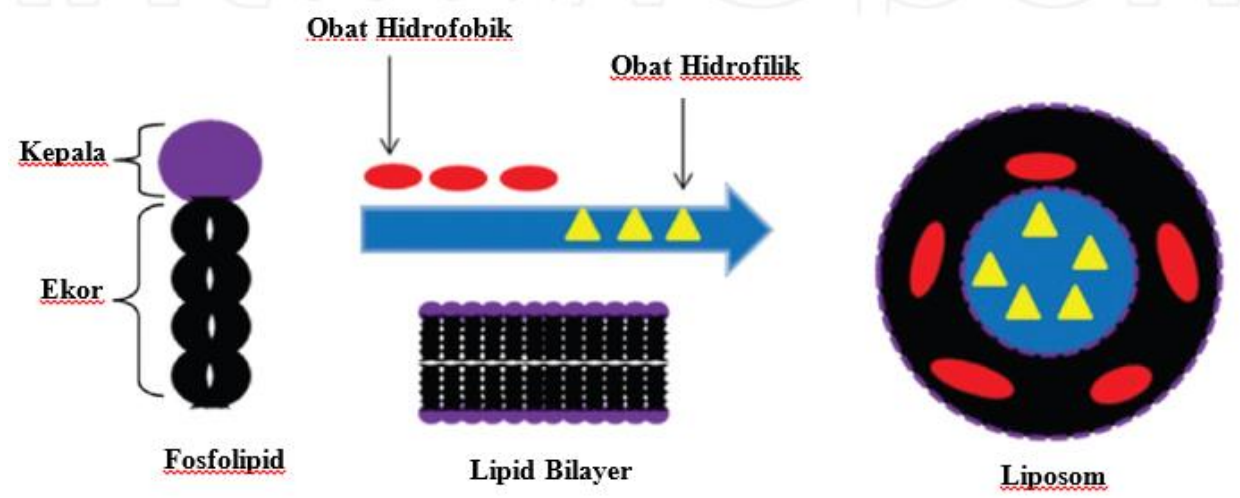

Gambar 4 Flowchart yang menggambarkan pembentukan liposom dan enkapsulasi molekul obat

\section{Kesimpulan}

Cathelicidin merupakan kelompok Peptida Antimikrobial (PAM) dengan berat molekul rendah yang memiliki berbagai aktivitas biologi pada rentang terapi tertentu. Struktur aheliks pada $C$ terminal bertanggung jawab atas efek antimikrobial, antikanker dan antivirus. Pengembangan cathelicidin sebagai obat telah memasuki uji klinik fase II dengan indikasi yang diajukan sebagai obat untuk ulserasi tungkai bawah (venous leg uler) yang bertujuan untuk meningkatkan penyembuhan luka pada kelompok pasien dengan luka yang tidak sembuh yang diformulasikan dalam bentuk sediaan gel. Walaupun menarik untuk aplikasi klinis, cathelicidin memiliki keterbatasan dalam hal stabilitas dan aktivitasnya secara in-vivo, serta interaksi non-spesifik dengan membran biologis inang yang mengarah pada efek sitotoksik yang merugikan. Keterbatasan cathelicidin tersebut dapat diatasi dengan mengenkapsulasi cathelicidin dalam pembawa lipid seperti liposom. Enkapsulasi cathelicidin dapat mengakibatkan penurunan sitotoksisitas, meningkatkan stabilitas dan aktivitas biologisnya. Selain itu, enkapsulasi dapat melindungi peptida dari degradasi 


\section{Daftar Pustaka}

1. Agier J, Efenberger M, Brzezińska-Błaszczyk E. Review paper Cathelicidin impact on inflammatory cells. Cent Eur J Immunol [Internet]. 2015;2(2):225-35. Available from: http://www.termedia.pl/doi/10.5114/ceji.2015.51359

2. Phoenix DA, Dennison SR, Harris F. Antimicrobial Peptides: Their History, Evolution, and Functional Promiscuity. In: Antimicrobial Peptides [Internet]. Weinheim, Germany: Wiley-VCH Verlag GmbH \& Co. KGaA; 2013. p. 1-37. Available from: http://doi.wiley.com/10.1002/9783527652853.ch1

3. Bals R. Epithelial antimicrobial peptides in host defense against infection. Respir Res [Internet]. 2000 Dec 20;1(3):5. Available from: http://respiratoryresearch.biomedcentral.com/articles/10.1186/rr25

4. Amer LS, Bishop BM, van Hoek ML. Antimicrobial and antibiofilm activity of cathelicidins and short, synthetic peptides against Francisella. Biochem Biophys Res Commun [Internet]. 2010 May;396(2):246-51. Available from: https://linkinghub.elsevier.com/retrieve/pii/S0006291X10007424

5. de Latour FA, Amer LS, Papanstasiou EA, Bishop BM, Hoek ML van. Antimicrobial activity of the Naja atra cathelicidin and related small peptides. Biochem Biophys Res Commun [Internet]. 2010 Jun;396(4):825-30. Available from: https://linkinghub.elsevier.com/retrieve/pii/S0006291X10008661

6. Kanthawong S, Bolscher JGM, Veerman ECI, van Marle J, de Soet HJJ, Nazmi K, et al. Antimicrobial and antibiofilm activity of LL-37 and its truncated variants against Burkholderia pseudomallei. Int J Antimicrob Agents [Internet]. 2012 Jan;39(1):39-44. Available from: https://linkinghub.elsevier.com/retrieve/pii/S0924857911003712

7. Eckert R. Road to clinical efficacy: challenges and novel strategies for antimicrobial peptide development. Future Microbiol [Internet]. 2011 Jun;6(6):635-51. Available from: https://www.futuremedicine.com/doi/10.2217/fmb.11.27

8. Mahlapuu M, Håkansson J, Ringstad L, Björn C. Antimicrobial Peptides: An Emerging Category of Therapeutic Agents. Front Cell Infect Microbiol [Internet]. 2016 Dec 27;6. Available from: http://journal.frontiersin.org/article/10.3389/fcimb.2016.00194/full

9. Nordström R, Malmsten M. Delivery systems for antimicrobial peptides. Adv Colloid Interface Sci [Internet]. 2017 Apr;242:17-34. Available from: https://linkinghub.elsevier.com/retrieve/pii/S0001868616303700

10. Chou H-T, Kuo T-Y, Chiang J-C, Pei M-J, Yang W-T, Yu H-C, et al. Design and synthesis of cationic antimicrobial peptides with improved activity and selectivity against Vibrio spp. Int J Antimicrob Agents [Internet]. 2008 Aug;32(2):130-8. Available from: https://linkinghub.elsevier.com/retrieve/pii/S092485790800160X

11. Umerska A, Cassisa V, Bastiat G, Matougui N, Nehme $H$, Manero F, et al. Synergistic interactions between antimicrobial peptides derived from plectasin and lipid nanocapsules containing monolaurin as a cosurfactant against Staphylococcus aureus. Int J Nanomedicine [Internet]. 2017 Aug;Volume 12:5687-99. Available from: https://www.dovepress.com/synergistic-interactions-between-antimicrobial-peptidesderived-from-p-peer-reviewed-article-IJN 
12. Sun L, Zheng C, Webster T. Self-assembled peptide nanomaterials for biomedical applications: promises and pitfalls. Int J Nanomedicine [Internet]. 2016 Dec;Volume 12:73-86. Available from: https://www.dovepress.com/self-assembled-peptidenanomaterials-for-biomedical-applications-promi-peer-reviewed-article-IJN

13. Wang L, Hu C, Shao L. The antimicrobial activity of nanoparticles: present situation and prospects for the future. Int J Nanomedicine [Internet]. 2017 Feb;12:1227-49. Available from: https://www.dovepress.com/the-antimicrobial-activity-ofnanoparticles-present-situation-and-pros-peer-reviewed-article-IJN

14. Garcia-Orue I, Gainza G, Girbau C, Alonso R, Aguirre JJ, Pedraz JL, et al. LL37 loaded nanostructured lipid carriers (NLC): A new strategy for the topical treatment of chronic wounds. Eur J Pharm Biopharm [Internet]. 2016 Nov;108:310-6. Available from: https://linkinghub.elsevier.com/retrieve/pii/S0939641116301308

15. Patel K, Chauhan D, Sodha R, Vadhwani K, Daxini K. Dermal Delivery of Protein and Peptides: Recent advances and clinical outcome. PharmaTutor. 2019;7(7):2131.

16. McCrudden MTC, McLean DTF, Zhou M, Shaw J, Linden GJ, Irwin CR, et al. The Host Defence Peptide LL-37 is Susceptible to Proteolytic Degradation by Wound Fluid Isolated from Foot Ulcers of Diabetic Patients. Int J Pept Res Ther [Internet]. 2014 Dec 17;20(4):457-64. Available from: http://link.springer.com/10.1007/s10989014-9410-3

17. Larrick JW, Hirata M, Balint RF, Lee J, Zhong J, Wright SC. Human CAP18: a novel antimicrobial lipopolysaccharide-binding protein. Infect Immun [Internet]. 1995;63(4):1291-7. Available from: https://iai.asm.org/content/63/4/1291

18. Duplantier AJ, van Hoek ML. The Human Cathelicidin Antimicrobial Peptide LL-37 as a Potential Treatment for Polymicrobial Infected Wounds. Front Immunol [Internet]. 2013;4(143).

Available

from: http://journal.frontiersin.org/article/10.3389/fimmu.2013.00143/abstract

19. Bandurska K, Berdowska A, Barczyńska-Felusiak R, Krupa P. Unique features of human cathelicidin LL-37. BioFactors [Internet]. 2015 Sep 10;41(5):289-300. Available from: http://doi.wiley.com/10.1002/biof.1225

20. Steinmann J. Induction and regulation of CAMP gene expression. University of Iceland; 2008.

21. Sørensen O, Cowland JB, Askaa J, Borregaard N. An ELISA for hCAP-18, the cathelicidin present in human neutrophils and plasma. J Immunol Methods. 1997 Aug;206(1-2):53-9.

22. Stapels DAC, Geisbrecht B V., Rooijakkers SHM. Neutrophil serine proteases in antibacterial defense. Curr Opin Microbiol [Internet]. 2015 Feb;23:42-8. Available from: https://linkinghub.elsevier.com/retrieve/pii/S1369527414001611

23. Sørensen OE, Follin P, Johnsen AH, Calafat J, Tjabringa GS, Hiemstra PS, et al. Human cathelicidin, hCAP-18, is processed to the antimicrobial peptide LL-37 by extracellular cleavage with proteinase 3. Blood [Internet]. 2001 Jun 15;97(12):39519. Available from: https://ashpublications.org/blood/article/97/12/3951/107245/Human-cathelicidinhCAP18-is-processed-to-the

24. Wong JH, Ng TB, Legowska A, Rolka K, Hui M, Cho $\mathrm{CH}$. Antifungal action of human cathelicidin fragment (LL13-37) on Candida albicans. Peptides. 2011 Oct;32(10):1996-2002. 
25. Dean SN, Bishop BM, van Hoek ML. Susceptibility of Pseudomonas aeruginosa Biofilm to Alpha-Helical Peptides: D-enantiomer of LL-37. Front Microbiol [Internet]. $2011 ; 2$. Available

from: http://journal.frontiersin.org/article/10.3389/fmicb.2011.00128/abstract

26. Barlow PG, Svoboda P, Mackellar A, Nash AA, York IA, Pohl J, et al. Antiviral Activity and Increased Host Defense against Influenza Infection Elicited by the Human Cathelicidin LL-37. Kovats S, editor. PLoS One. 2011 Oct;6(10):e25333.

27. Wong JH, Legowska A, Rolka K, Ng TB, Hui M, Cho CH, et al. Effects of cathelicidin and its fragments on three key enzymes of HIV-1. Peptides. 2011 Jun;32(6):111722.

28. Rico-Mata R, De Leon-Rodriguez LM, Avila EE. Effect of antimicrobial peptides derived from human cathelicidin LL-37 on Entamoeba histolytica trophozoites. Exp Parasitol. 2013 Mar;133(3):300-6.

29. Davidson DJ, Currie AJ, Reid GSD, Bowdish DME, MacDonald KL, Ma RC, et al. The Cationic Antimicrobial Peptide LL-37 Modulates Dendritic Cell Differentiation and Dendritic Cell-Induced T Cell Polarization. J Immunol. 2004 Jan;172(2):114656.

30. Salvado MD, Di Gennaro A, Lindbom L, Agerberth B, Haeggström JZ. Cathelicidin LL-37 Induces Angiogenesis via PGE 2 -EP3 Signaling in Endothelial Cells, In Vivo Inhibition by Aspirin. Arterioscler Thromb Vasc Biol. 2013 Aug;33(8):1965-72.

31.Pfosser A, El-Aouni C, Pfisterer I, Dietz M, Globisch F, Stachel G, et al. NF îoB Activation in Embryonic Endothelial Progenitor Cells Enhances Neovascularization Via PSGL-1 Mediated Recruitment: Novel Role for LL37. Stem Cells. 2009;N/A-N/A.

32. Ramos R, Silva JP, Rodrigues AC, Costa R, Guardão L, Schmitt F, et al. Wound healing activity of the human antimicrobial peptide LL37. Peptides. 2011 Jul;32(7):1469-76.

33. Coffelt SB, Marini FC, Watson K, Zwezdaryk KJ, Dembinski JL, LaMarca HL, et al. The pro-inflammatory peptide LL-37 promotes ovarian tumor progression through recruitment of multipotent mesenchymal stromal cells. Proc Natl Acad Sci. 2009 Mar;106(10):3806-11.

34. Kai-Larsen Y. The role of the multifunctional peptide LL-37 in host defense. Front Biosci. 2008;Volume(13):3760.

35. National Center for Biotechnology Information. PubChem Database. LL-37, Source=IUPHAR/BPS Guide to PHARMACOLOGY, SID=178102170. 2020.

36. Porcelli F, Verardi R, Shi L, Henzler-Wildman KA, Ramamoorthy A, Veglia G. NMR Structure of the Cathelicidin-Derived Human Antimicrobial Peptide LL-37 in Dodecylphosphocholine Micelles †. Biochemistry. 2008 May;47(20):5565-72.

37. Guangshun W. Structures of Human Host Defense Cathelicidin LL-37 and Its Smallest Antimicrobial Peptide KR-12 in Lipid Micelles. J Biol Chem. 2008 Nov;283(47):32637-43.

38. Wang G. Human Antimicrobial Peptides and Proteins. Pharmaceuticals [Internet]. 2014 May 13;7(5):545-94. Available from: http://www.mdpi.com/1424-8247/7/5/545

39. Burton MF, Steel PG. The chemistry and biology of LL-37. Nat Prod Rep. 2009;26(12):1572.

40. Grönberg A, Dieterich C, Mahlapuu M. U.S. Patent No. 10,226,508. Washington, DC; 2019. 
41. Öhnstedt E, Lofton Tomenius H, Vågesjö E, Phillipson M. The discovery and development of topical medicines for wound healing. Expert Opin Drug Discov. 2019 May;14(5):485-97.

42. Scott MG, Davidson DJ, Gold MR, Bowdish D, Hancock REW. The Human Antimicrobial Peptide LL-37 Is a Multifunctional Modulator of Innate Immune Responses. J Immunol. 2002 Oct;169(7):3883-91.

43. Tokumaru S, Sayama K, Shirakata Y, Komatsuzawa H, Ouhara K, Hanakawa Y, et al. Induction of Keratinocyte Migration via Transactivation of the Epidermal Growth Factor Receptor by the Antimicrobial Peptide LL-37. J Immunol. 2005 Oct;175(7):4662-8.

44. Koczulla R, von Degenfeld G, Kupatt C, Krötz F, Zahler S, Gloe T, et al. An angiogenic role for the human peptide antibiotic LL-37/hCAP-18. J Clin Invest. 2003 Jun;111(11):1665-72.

45. Ron-Doitch S, Sawodny B, Kühbacher A, David MMN, Samanta A, Phopase J, et al. Reduced cytotoxicity and enhanced bioactivity of cationic antimicrobial peptides liposomes in cell cultures and 3D epidermis model against HSV. J Control Release [Internet]. $2016 \quad$ May;229:163-71. Available from: https://linkinghub.elsevier.com/retrieve/pii/S0168365916301596

46. Angelova A, Garamus VM, Angelov B, Tian Z, Li Y, Zou A. Advances in structural design of lipid-based nanoparticle carriers for delivery of macromolecular drugs, phytochemicals and anti-tumor agents. Adv Colloid Interface Sci. 2017 Nov;249:331-45.

47. Matougui N, Boge L, Groo A-C, Umerska A, Ringstad L, Bysell H, et al. Lipid-based nanoformulations for peptide delivery. Int J Pharm. 2016 Apr;502(1-2):80-97.

48. Fumakia M, Ho EA. Nanoparticles Encapsulated with LL37 and Serpin A1 Promotes Wound Healing and Synergistically Enhances Antibacterial Activity. Mol Pharm [Internet]. 2016 Jul 5;13(7):2318-31. Available from: https://pubs.acs.org/doi/10.1021/acs.molpharmaceut.6b00099

49. Boge L, Hallstensson K, Ringstad L, Johansson J, Andersson T, Davoudi M, et al. Cubosomes for topical delivery of the antimicrobial peptide LL-37. Eur J Pharm Biopharm. 2019 Jan;134:60-7.

50. Bangham AD, Standish MM, Weissmann G. The action of steroids and streptolysin $S$ on the permeability of phospholipid structures to cations. J Mol Biol. 1965 Aug;13(1):253-IN28.

51. Gregoriadis G, Florence AT. Liposomes in Drug Delivery. Drugs. 1993 Jan;45(1):1528.

52. Kraft JC, Freeling JP, Wang Z, Ho RJY. Emerging Research and Clinical Development Trends of Liposome and Lipid Nanoparticle Drug Delivery Systems. J Pharm Sci. 2014 Jan;103(1):29-52.

53. Akbarzadeh A, Rezaei-Sadabady R, Davaran S, Joo SW, Zarghami N, Hanifehpour Y, et al. Liposome: classification, preparation, and applications. Nanoscale Res Lett [Internet]. $2013 \quad$ Dec 22;8(1):102. Available from: https://nanoscalereslett.springeropen.com/articles/10.1186/1556-276X-8-102

54. Gregoriadis G, Perrie Y. Liposomes. In Encyclopedia of Life Sciences (ELS). Chichester: John Wiley \& Sons, Ltd; 2010. 
55. Laouini A, Jaafar-Maalej C, Limayem-Blouza I, Sfar S, Charcosset C, Fessi H. Preparation, Characterization and Applications of Liposomes: State of the Art. J Colloid Sci Biotechnol [Internet]. 2012 Dec 1;1(2):147-68. Available from: http://www.ingentaconnect.com/content/10.1166/jcsb.2012.1020

56. Bozzuto G, Molinari A. Liposomes as nanomedical devices. Int J Nanomedicine [Internet]. $2015 \quad$ Feb;10(1):975. Available from: http://www.dovepress.com/liposomes-as-nanomedical-devices-peer-reviewedarticle-IJN

57. Shashi, K., Satinder, K., \& Bharat P. A complete review on: Liposomes. Int Res J Pharm. 2012;3(7):10-6.

58. Patil YP, Jadhav S. Novel methods for liposome preparation. Chem Phys Lipids. 2014 Jan;177:8-18.

59. Khadke S, Stone P, Rozhin A, Kroonen J, Perrie Y. Point of use production of liposomal solubilised products. Int J Pharm. 2018 Feb;537(1-2):1-8.

60. Goñi FM. The basic structure and dynamics of cell membranes: An update of the Singer-Nicolson model. Biochim Biophys Acta - Biomembr [Internet]. 2014 Jun;1838(6):1467-76.

Available

https://linkinghub.elsevier.com/retrieve/pii/S000527361400008X

61. Lila ASA, Ishida T. Liposomal Delivery Systems: Design Optimization and Current Applications. Biol Pharm Bull [Internet]. 2017;40(1):1-10. Available from: https://www.jstage.jst.go.jp/article/bpb/40/1/40_b16-00624/_article

62. Pattni BS, Chupin V V., Torchilin VP. New Developments in Liposomal Drug Delivery. Chem Rev [Internet]. 2015 Oct 14;115(19):10938-66. Available from: https://pubs.acs.org/doi/10.1021/acs.chemrev.5b00046 